\title{
Current focuses in woody plant water relations and drought resistance
}

\author{
T.M. Hinckley ${ }^{1}$ and R. Ceulemans ${ }^{2}$ \\ 1 College of Forest Resources, University of Washington, Seattle, WA 98195, U.S.A., and \\ 2 Departmental of Biology, University of Antwerp, Universiteitsplein 1, B-2610 Wilrijk, Belgium
}

\section{Introduction}

Stress, such as drought, affects physiological processes and is the result of one or a combination of environmental and biological factors. The degree of stress is related both to the degree of change in the process as well as the amount of energy expended by the plant to resist and recover from the stress. Although zero stress seldom, if ever, occurs in plants, and, in particular, plants growing in the field, it has theoretical and experimental relevance. Drought stress may be induced by environmental (e.g., low precipitation, low humidity, cold temperature, etc.) or biotic (e.g., root decaying fungus, xylem borers, etc.) factors which cause plant water potential to decrease below levels which maintain optimal growth and development. Plants resist drought stress by postponing dehydration and/or by tolerating dehydration. The degree to which a plant utilizes these mechanisms will be species and tissue dependent. The level of drought resistance achieved by using such mechanisms will be species, tissue, developmental stage and life history dependent.
Since the advent of the pressure chamber, the porometer and the pressure-volume technique in the mid to late 1960s, there has been a dramatic increase in the number of studies on drought resistance of plants. Much of this work has been comparative in nature and has had a single organ focus (e.g., leaf level). More recently, there has been an increased emphasis on scaling from the organ level either to the whole plant or stand level or to the molecular/biophysical level.

In this paper, we will examine 3 aspects of the water relations and drought resistance of forest trees: 1) the movement of water in plants and its regulation; 2) the interaction between stomatal responses and water movement; and 3) allometric relationships or the expression of functional relationships at the structural level. We will examine both the historical foundation as well as the current status of these 3 aspects. Finally, we will present a number of research topics which have resulted as a consequence of a broader examination of these 3 aspects. Because of the presence of a large number of fairly recent, excellent reviews on drought resistance (e.g. Hennessey et al., 1986; Koz- 
lowski, 1968-1983; Kramer, 1983; Levitt, 1980; Meidner, 1983; Paleg and Aspinall, 1981; Schulze, 1986; Stone and Willis, 1983; Teare and Peet, 1983; Turner and Kramer, 1980; Turner, 1986), this paper will not be a review of this literature. Instead, we will assume that it is at the interface of a number of areas (e.g., hydraulic architecture and stomatal function) and under the effort of scaling up or down from the leaf that exciting new ideas about how plants resist stress will be forthcoming. Our paper will deal with a number of these interfaces as well as with scaling, particularly to the whole plant level.

It is also our contention that studies with a singular focus at the leaf level lack innovation and that, unless scaled either up or down, will not significantly contribute to our understanding of either the mechanisms of response or the pattern and integration at the whole plant level of response. For these reasons, we will try to assume a whole plant focus.

\section{Discussion}

Individuals responsible for key observations or important developments in 3 areas of plant water relations (i.e., stomatal control, movement of water in plants and allometry) have been identified in Fig. 1 (sources: Aloni, 1987; Huber, 1956; Jarvis, 1975; Kramer, 1983; Meidner, 1987; Reed 1942; Zimmermann, 1983; as well as original literature: e.g., Askenasy, 1895; Bode, 1923; Böhm, 1893; Darwin, 1898; Dixon and Joly, 1895; Ewart, 1905; Gradmann, 1928; Hales, 1727; Hartig, 1878; Huber, 1924; Jost, 1913; Sachs, 1882). Although it might be most appropriate to examine in detail much of this early work, it suffices here to summarize with 3 gener- alizations. First, most, if not all, current observations and concepts not only have their roots in the past, but they are largely repetitive of past observations and conclusions. Second, elegant research does not by necessity equate itself with elegant equipment. Finally, many of the scientists listed in Fig. 1 were either physicists or very well trained in physics. These observations would probably hold whether one did this examination today or 100 years from today. Although it seems that articles published in the 1960s and 1970s are already dated, we would strongly suggest that the historical literature not be neglected. Based upon this examination as well as our appreciation of current research, we have identified for areas further discussion (Fig. 1).

\section{Stomatal activity}

Key to a vastly improved understanding of the role of stomatal activity in plants has been the acceptance that properties of the water potential equation measured at the bulk leaf level are at best correlated with stomatal aperture and that the entire plant has an impact on the response of a given leaf's stomata (Davies et al., 1988; Frensch and Schulze, 1988; Küppers et al., 1988; Masle and Passioura, 1987; Munns and King, 1988; Richter, 1973; Schulte and Hinckley, 1987; Teskey et al. 1983; Tyree and Sperry, 1988). A summary of the above work includes the following points: 1) the importance of isolating the water potential of the guard cell complex from that of the bulk leaf; 2) the biochemi$\mathrm{cal}$ and biophysical roles that roots have in sensing the soil environment; and 3 ) the biophysical and perhaps biochemical role that shoots play in sensing their environment. This subject is covered in greater detail by Dr. Gollan in these proceedings. 


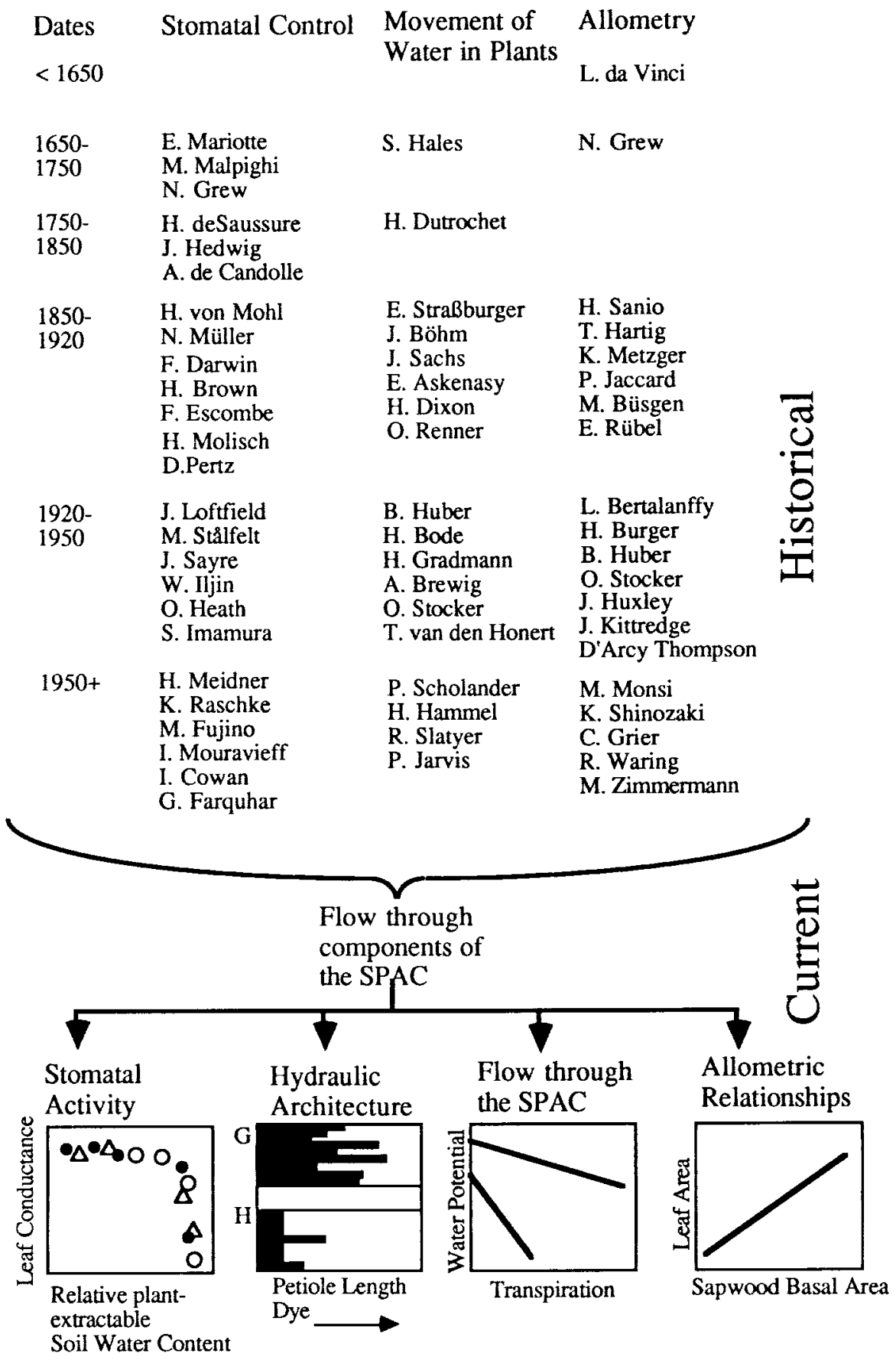

Fig. 1. Historical perspective on 4 current aspects of water relations in trees. 


\section{Hydraulic architecture}

The important role that xylem anatomy and hydraulic architecture at the crown level play on the water relations of trees has been described in these proceedings by Tyree and Sperry as well as extensively in the literature (Dickson and Isebrands, 1988; Schulte et al., 1987; Sperry and Tyree, 1988; Tyree, 1988; Tyree and Sperry, 1988; Zimmermann, 1978, 1983). Two important conclusions are derived from this work: 1) all species may operate near the brink of catastrophic xylem dysfunction due to dynamic water stress (where stomata play a key role; and 2) the branches of a tree might be regarded as a collection of small independent plantlets, each 'rooted' in the bole. This latter observation can be nicely integrated into the concept of autonomous branches based upon a carbon budget (Sprugel and Hinckley, 1988). The former observation is interestingly similar to conclusions reached by Richter (1976) and others that many species operate near the osmotic potential when turgor will be zero (e.g., Hinckley et al., 1983; Fig. 2). An interesting research topic would be a study of the interaction between the point of catastrophic xylem dysfunction and osmotic potential especially as periods of diurnal or seasonal osmotic adjustment are noted. The presence of xylem-tapping mistletoes in which stomatal opening has been observed, while the stomata of the host's foliage is closed and its impact on hydraulic architecture would be another topic (Glatzel, 1983; Schulze, 1986).

Flow through the soil-plant-atmosphere continuum (SPAC)

Currently, 2 models, based upon the catenary theory of water flow (Huber, 1924; van den Honert, 1948), are used to de- scribe flow through the soil-plant-atmosphere continuum: 1) unbranched (e.g., Elfving et al., 1972) and 2) branched catena models (e.g., Richter, 1973; Tyree, 1988). Most typically the latter model includes considerations of both the consequences of branching structure and tissue capacitance. Although the former model represents a gross over-simplification of the nature of flow through a tree, it has useful interpretative functions (e.g., Kaufmann, 1975; Kjelgren, 1988). From these 2 models, a consideration of the factors controlling water movement within the SPAC has been forthcoming. As pointed out by van den Honert (1948) and Jarvis (1975), water loss from the plant is controlled at the liquid-air interface and, therefore, is only affected through changes in leaf conductance. However, the relative importance of this point in the pathway has been argued both by those examining flow through the components of a single indivicual (e.g., Kaufmann, 1975; Running, 1980; Passioura, 1988; Teskey et al., 1984; Tyree, 1988; Tyree and Sperry, 1988) and by those scaling from the leaf to the landscape (e.g., Jarvis and McNaughton, 1986).

\section{Allometry}

As illustrated in Fig. 1, from as early as Leonardo da Vinci, scientists have been interested in how various parts of an organism are related both functionally and structurally and how changes in development and stress affect these relationships. Although the fields of mensuration and forest measurements are based upon allometric relationships, it was not until the publication of 2 papers in 1964 by Shinozaki et al., that an interest in allometric relationships arnongst physiological ecologists developed (e.g., Waring et al., 1982; Schulze, 1986). Such studies have ele- 
gantly shown that there is a functional equilibrium between the various parts of a tree. In very young material or within a given branch or root system, this equilibrium may be quite dynamic; however, when one scales to the whole tree, the response time is increased. As will be discussed later, when interest in allometry is combined with interest in one or more of the other aspects just discussed, some very fruitful observations can be made.

Two areas which represent combinations of the 4 subjects just discussed appear to hold promise for improving our understanding of how tissues within a tree function both at the tissue and at the whole tree level. First, the area of root-toshoot (or foliage) communication, in a sense a combination of all 4 subjects, is extremely exciting. The biophysical interaction between the root and the shoot has long been recognized; however, the nature of how a change in water potential or water flow is sensed are still not well understood (e.g., Teskey et al., 1983). In the mid-1970s, Dr. Rolf Borchert conducted a number of very elegant experiments from which he concluded that there was an intimate feedback system between root and foliage expansion (Borchert, 1975). Using a split-root design, Blackman and Davies (1985) demonstrated that sto- matal closure occurred in Heliannthus annus, not as a consequence of changes in foliar water potential, but because $50 \%$ of the root system was in a dry soil, was not growing and, as a consequence, was sending biochemical messages to the foliage. More recent studies (Davies et al., 1988; Küppers et al., 1988; Masle and Passioura, 1987; Munns and King, 1988; Passioura, 1988) have increased our understanding of the importance of the rapid biochemical interaction between the root and the foliage. Table I represents our sense of the relative importance of biochemical and biophysical communications between the root and shoot in a variety of different types of trees. For example, relatively little is known about the importance of biochemical communication in the short-term in conifers. The clarification of the role that biochemical, nutritional and/or biophysical messages play in root-to-foliage communication will clearly be an important topic of the next decade (Kuiper and Kuiper, 1988). In our effort to discover a or the biochemical messenger, Moss et al. (1988) caution: "... (that there is) the danger of proposing a causal role for hormones in developmental (or physiological) phenomena on the basis of correlative evidence of joint occurrence between changes in the titre of hormone and the physiological process of interest."

Table I. Hypothetical relationship between vascular anatomy, plant size and relative importance of root-foliage communication (short-term basis).

\begin{tabular}{lllll}
\hline $\begin{array}{l}\text { Nature of vascular } \\
\text { system }\end{array}$ & $\begin{array}{l}\text { Rate of } \\
\text { sap flow }\end{array}$ & $\begin{array}{l}\text { Size of } \\
\text { tree }\end{array}$ & $\begin{array}{l}\text { Root-to-foliage communicationa } \\
\text { biophysical }\end{array}$ \\
\hline Tracheid & slow & $\begin{array}{l}\text { small } \\
\text { large }\end{array}$ & \\
Diffuse-porous & moderate & $\begin{array}{l}\text { small } \\
\text { large }\end{array}$ & small \\
Ring-porous & lasge & & \\
\hline
\end{tabular}

aColumns under biophysical or biochemical should only be compared vertically. 
Another area that is clearly interesting is the interface between hydraulic architecture and allometric relationships. As reported in this conference by Pothier, Margolis and Waring, when saturated sapwood permeability (i.e., relative conductivity; Jarvis, 1975) at the base of the live crown rather than sapwood area was measured, the effects of age and site quality could be nicely isolated. They hypothesized that age-related increases in saturated sapwood permeability could explain how trees can maintain similar daytime leaf water potentials at different stages of development. However, Carter and Smith (1988) have noted that, although water potentials may be quite similar in different conifer species at different stages of development, leaf conductances are not. Differences in leaf conductance may reflect differences in photosynthetic potential or higher relative conductivity or both.

When studies of water relations are related to other whole plant studies of carbon and nutrient relations, a vastly improved understanding of how trees function under both optimal and stress conditions should be forthcoming. This conference has provided an excellent intellectual framework from which such studies may continue and be forthcoming.

\section{Acknowledgments}

Partial funding provided under subcontract no. 19X-43382C with the Oak Ridge National Laboratory under Martin Marietta Energy Systems, Inc. contract DE-AC05-840R21400 with the U.S. Department of Energy. Title of Project: 'Genetic Improvement and Evaluation of Black Cottonwood for Short-Rotation Culture', R.F. Stettler, P.E. Heilman and T.M. Hinckley, principal investigators. A special thanks to Drs. G. Goldstein, D. Pothier, H. Margolis, R. Waring, J. Sperry and M. Tyree for making unpublished data available. A special thanks to Drs. R.B.
Walker and $\mathrm{H}$. Richter for numerous discussions about the historical foundations of the current thinking in plant-water relations.

\section{References}

Aloni R. (1987) Differentiation of vascular tissues. Annu. Rev. Plant Physiol. 38, 179-204

Askenasy E. (1895) Über das saftsteigen. Bot. Zentralbl. 62, 237-238

Blackman P.G. \& Davies W.J. (1985) Root to shoot communication in maize plants of the effects of soil drying. J. Exp. Bot. 36, 39-48

Bode H.R. (19ż3) Beiträge zur dynamik der wasserbewegung in den gefässpflanzen. Jahr. Wiss. Bot. 62, 92-127

Böhm J. (1893) Capillarität und saftsteigen. Ber. Deutsch Bot. Ges. 11, 203-212

Borchert R. (1975) Endogenous shoot growth under constant conditions. Physiol. Plant. 35, 152-157

Büsgen M. \& Münch B. (1929) In: The Structure and Life of Forest Trees. (Thomson T., translator). Chapman \& Hall, Ltd., London, pp. 436

Carter G.A. \& Smith W.K. (1988) Microhabitat comparisons of transpiration and photosynthesis in three subalpine conifers. Can. J. Bot. 66, 963-969

Darwin F. (1898) Observations on stomata. Philos. Trans. R. Soc. London B. 190, 531-621

Davies W.J., Metcalfe, J.C., Schurr U., Taylor C. \& Zhang J. (1988) Hormones as chemical signals involved in root to shoot communication of effects of changes in the soil environment. In: Hormone Action in Plant Development - A Critical Appraisal (Hoad G.V., Jackson M.B., Lenton J.R. \& Aitken R., eds.), Butterworths, London, (in pressi)

Dickson R.E. \& Isebrands J.G. (1989) Role of leaves in regulating structure-functional development in plant shoots. In: Integrated Response of Plants to Stress. (Mooney H.A., Winner W.E. \& Pell E.J., eds.), Academic Press, London, (in press)

Dixon H.H. \& Joly J. (1895) On the ascent of sap. Philos. Trans. R. Soc. London B. 186, 563576

Elfving D.C., Kaufmann M.R. \& Hall A.E. (1972) Interpreting leaf water potential measurements with a model of the SPAC. Physiol. Plant. 27, $161-168$ 
Ewart A.J. (1905) The ascent of water in trees. Philos. Trans. R. Soc. London B. 198, 41-85

Frensch J. \& Schulze E.D. (1988) The effect of humidity and light on cellular water relations and diffusion conductance of leaves of Trandescantia virginiana L. Planta 173, 554-562

Glatzel G. (1983) Mineral nutrition and water relations of hemiparasitic mistletoes: a question of partitioning. Experiments with Loranthus europaeus on Quercus petraea and Quercus robur. Oecologia 56, 193-201

Gradmann H. (1928) Untersuchungen über die wasserverhältnisse des bodens als grundlage des pflanzenwachstums. Jahrb. Wiss. Bot. 69, $1-100$

Hales S. (1727) in: Vegetable Staticks. (Innys W.J. and Woodward T., Compilers), London Scientific Book Guild

Hartig T. (1878) In: Anatomie und Physiologie der Holzpflanzen. J. Springer, Berlin

Henessey T.C., Dougherty P.M., Kossuth S.V. \& Johnson J.D. (1986) In: Stress Physiology and Forest Productivity. Martinus Nijhoff Publ., Dordrecht, pp. 239

Hinckley T.M., Duhme F., Hinckley A.R. \& Richter H. (1983) Drought relations of shrub species: assessment of the mechanisms of drought resistance. Oecologia 59, 344-350

Huber B. (1924) Die beurteilung des wasserhaushaltes der pflanze. Ein beitrag zur vergleichenden physiologie. Jahrb. Wiss. Bot. 64, 1120

Huber B. (1956) Die gefässleitung. In: Encyclopedia of Plant Physiology Vol. III (Ruhland W., ed.), Springer-Verlag, Berlin

Jarvis P.G. (1975) Water transfer in plants. In: Heat and Mass Transfer in the Biosphere (de Vries D.A. \& Afgan N.H., eds.), Scripta Book. Co., Washington, D.C., Vol. I, pp. 369-394

Jarvis P.G. \& McNaughton K.G. (1986) Stomatal control of transpiration: scaling up from leaf to region. Adv. Ecol. Res. 15, 1-49

Jost L. (1913) In: Vorlesungen über Pflanzenphysiologie. Gustav Fischer, Jena, pp. 760

Kaufmann M.R. (1975) Leaf water stress in Engelmann spruce: influence of root and shoot environments. Plant Physiol. 56, 841-844

Kjelgren R. (1988) Development of Liquidambar styraciflua $L$. in three urban microclimates. Ph.D. Dissertation, University of Washington, Seattle
Kozlowski T.T. (ed.) (1968-1983) In: Water Deficits and Plant Growth. Vol. I-VII. Academic Press, New York

Kramer P.J. (1983) In: Plant and Soil Water Relationships. Academic Press. New York, pp. 483

Kuiper D. \& Kuiper P.J.C. (1988) Phenotypic plasticity in a physiological perspective. Acta Oecol. 9, 43-59

Küppers B.I.L., Küppers M. \& Schulze E.D. (1988) Soil drying and its effect on leaf conductance and $\mathrm{CO}_{2}$ assimilation of Vigna unguiculata (L.) Walp. I. The response to climatic factors and to the rate of soil drying in young plants. Oecologia 75, 99-104

Levitt J. (1980) In: Responses of Plants to Environmental Stresses. Vol. II. Water, Radiation, Salt and Other Stresses. Academic Press. London, pp. 607

Masle J. \& Passioura J.B. (1987) The effect of soil strength on the growth of young wheat plants. Aust. J. Plant Physiol. 14, 643-656

Meidner H. (1983) Our understanding of plant water relations. J. Exp. Bot. 34, 1606-1618

Meidner $H$. (1987) Three hundred years of research into stomata. In: Physiology of Stomata (Ziegler E., ed.), Stanford University Press, Stanford, pp. 7-27

Moss G.I., Hall K.C. \& Jackson M.B. (1988) Ethylene and the responses of roots of maize (Zea mays L.) to physical impedance. New Phytol. 109, 303-311

Munns R. \& King R.W. (1988) Abscisic acid is not the only stomatal inhibitor in the transpiration stream of wheat plants. Plant Physiol. 88, 703-708

Paleg L.G. \& Aspinall D. (1981) In: The Physiology and Biochemistry of Drought Resistance in Plants. Academic Press, New York, pp. 492

Passioura J.P. (1988) Water uptake and transport in roots. Annu. Rev. Plant Physiol. Mol. Biol. 39, 245-265

Reed H.S. (1942) In: A Short History of the Plant Sciences. Chronica Botanica, Waltham, MA, pp. 320

Richter H. (1973) Frictional potential losses and total water potential in plants: a reevaluation. $J$. Exp. Bot. 24, 983-994

Richter H. (1976) The water status in the plant - experimental evidence. Ecol. Stud. 19, 42-58 
Running S.W. (1980) Field estimates of root and xylem resistances in Pinus contorta using root excision. J. Exp. Bot. 31, 555-569

Sachs J. (1882) In: Textbook of Botany; Morphological and Physiological (Vines S.H., translator), Clarendon Press, Oxford, pp. 980

Schulte P.J. \& Hinckley T.M. (1987) The relationship between guard cell water potential and the aperture of stomata in Populus. Plant Cell Environ. 10, 313-318

Schulte P.J., Gibson A.C. \& Nobel P.S. (1987) Xylem anatomy and hydraulic conductance of Psilotum nudum. Am. J. Bot. 74, 1438-1445

Schulze E.D. (1986) Whole-plant responses to drought. Aust. J. Plant Physiol. 13, 127-141

Shinozaki K., Yoda K., Hozumi K. \& Kira T. (1964a) A quantitative analysis of plant form the pipe model theory. I. Basic analyses. Jpn. J. Ecol. 14, 97-105

Shinozaki K., Yoda K., Hozumi K. \& Kira T. (1964b) A quantitative analysis of plant form the pipe model theory. II. Further evidence of the theory and its application in forest ecology. Jpn. J. Ecol. 14, 133-139

Sperry J.S. \& Tyree M.T. (1988) Mechanism of water stress-induced xylem embolism. Plant Physiol. 88, 581-587

Sprugel D.G. \& Hinckley T.M. (1988) The branch autonomy concept. In: Response of Trees to Air Pollution: The Role of Branch Studies. (Winner W.E. \& Phelps L.G., eds.), Proc. Workshop National Forest Response Program. Boulder, CO, 5-6 Nov. 1987, pp. 7-23

Stone J.F. \& Willis W.O. (1983) In: Plant Production and Management Under Drought Conditions. Elsevier Science Publishers B.V., Amsterdam, pp. 389
Teare I.E. \& Peet M.M. (1983) In: Crop-Water Relations. John Wiley \& Sons. New York, pp. 547

Teskey R.O., Hinckley T.M. \& Grier C.C. (1983) Effect of interruption of flow path on stomatal conductance of Abies amabilis. J. Exp. Bot. 34, 1251-1259

Teskey R.O., Hinckley T.M. \& Grier C.C. (1984) Temperature-induced changes in the water relations of Abies amabilis (Dougl.) Forbes. Plant Physiol. 74, 77-80

Turner N.C. (1986) Adaptation to water deficits: a changing perspective. Aust. J. Plant Physiol. $13,175-190$

Turner N.C. \& Kramer P.J. (1980) In: Adaptation of Plants to Water and High Temperature Stress. John Wiley \& Sons, New York

Tyree M.T. (1988) A dynamic model for water flow in a single tree. Tree Physiol. 4, 195-217

Tyree M.T., Sperry J.S. (1988) Do woody plants operate near the point of catastrophic xylem dysfunction caused by dynamic water stress? Answers from a model. Plant Physiol. 88, 574580

van den Honert T.H. (1948) Water transport in plants as a catenary process. Discuss. Faraday Soc. 3, 146-153

Waring R.H., Schroeder P.E. \& Oren R. (1982) Application of the pipe model theory to predict canopy leaf area. Can. J. For. Res. 12, 556-560

Zimmermann M.H. (1978) Hydraulic architecture of some diffuse-porous trees. Can J. Bot. 56, 2286-2295

Zimmermann M.H. (1983) In: Xylem Structure and the Ascent of Sap. Springer-Verlag, Berlin, pp. 143 